\title{
CONFLICTING APPROACHES TO CONFLICTS OF JURISDICTION: THE BRUSSELS CONVENTION AND FORUM NON CONVENIENS
}

\author{
Christopher D Bougen*
}

In developing an earlier article, published as "Time to Revisit Forum Non Conveniens in the United Kingdom? Group Josi Reinsurance Co v UGIC (2000) 32 VUWLR 705, this paper takes the debate further. The discretionary doctrine of forum non conveniens continues to be a controversial doctrine, and its relationship with the mandatory jurisdiction provisions of the Brussels Convention often leads to courts considering the correct methodology. Due to the seemingly growing acceptance of an expansive view of the scope of the Convention, this article looks to the future of forum non conveniens in the United Kingdom. Seemingly, there is sufficient flexibility within the Convention, for its jurisdiction rules to be the sole determinant of jurisdiction.

\section{INTRODUCTION}

The world of global commerce brings with it increasing cross-border activity and, as a natural consequence, legal disputes that also transcend national boundaries. Where parties to such disputes find themselves before a court, one of the first issues that arises is where should the case be heard: the courts of which country have jurisdiction to hear the case? Jurisdiction disputes have become something of an opening stanza for much of the interjurisdiction litigation that comes before a court. It has been observed, for example, that "in the American civil litigation system today, few cases reach trial. After perhaps some initial skirmishing, most cases settle. Yet all cases entail forum selection, which has a major impact

* LLB (Kobe University, Japan); LLM (Kobe University, Japan). Submitted for the LLB(Hons) degree at Victoria University of Wellington. This paper received the Robert Orr McGechan Memorial Prize for 2001. 
on outcome". ${ }^{1}$ Simply put, "venue is worth fighting over because outcome often turns on forum". ${ }^{2}$

This situation is clearly far from satisfactory. As Professor Schlosser, in his 1979 report on the Brussels Convention remarked, "a plaintiff must be sure which court has jurisdiction. He should not have to waste his time and money risking that the court concerned may consider itself less competent than another". ${ }^{3}$

This paper examines two disparate schemes that attempt to settle questions of jurisdiction in cases that have a cross-border element and involve two or more competent courts competing for jurisdiction. It explores the approach of the 1968 Convention on Jurisdiction and the Enforcement of Judgments in Civil and Commercial Matters (Brussels Convention), a convention between European Union member countries that addresses jurisdiction disputes, and also the approach adopted under the domestic rules and jurisprudence of private international law in the United Kingdom. The paper highlights the conflicting philosophies and approaches to the resolution of conflicts of jurisdiction and in particular focuses on the dispute as to whether the discretionary power to stay proceedings on the ground of forum non conveniens survives in the United Kingdom, given that the United Kingdom is a Contracting State of the Brussels Convention. This debate has been continuing for some time, with the United Kingdom Courts seemingly reluctant to depart from the discretionary determination of jurisdiction under the doctrine of forum non conveniens in favour of the more rigid rule-based approach adopted by Continental European countries and the Brussels Convention. Recent judicial developments in Europe and the United Kingdom are considered in this context. The central question considered in this paper is the compatibility of the Brussels Convention and the doctrine of forum non conveniens. Is a stay of proceedings on these grounds still available and should it still be available?

\section{THE APPROACH OF THE BRUSSELS CONVENTION TO DETERMINATION OF JURISDICTION AND CONFLICTS OF JURISDICTION}

The Brussels Convention was created for the purpose of addressing questions of jurisdiction arising among member states of the European Union by providing mandatory rules for determining jurisdiction in matters that come within the scope of the Convention.

1 Kevin M Clermont and Theodore Eisenberg "Exorcising the Evil of Forum-Shopping" (1995) 80 Cornell L Rev 1507, 1508.

2 Clermont and Eisenberg, above.

3 Peter F Schlosser "Report on the Convention on the Accession of the Kingdom of Denmark, Ireland, and the United Kingdom to the Brussels Convention" (1979) C 59/71, para 78. 
In the Jenard report on the Brussels Convention, one of the purposes of the Convention was described as achieving the greatest possible legal certainty by establishing common rules of jurisdiction. ${ }^{4}$

The Brussels Convention provides that as a general rule the courts of the defendant's domicile are to have jurisdiction. ${ }^{5}$ This rule is based on the maxim actor sequitur forum rei, the rationale being that it is easier, in principle, for a defendant to defend themselves in courts of their location. ${ }^{6}$ This general rule is subject only to the limited specific exceptions provided for in the Brussels Convention. These rules of special jurisdiction provide, for example, that the defendant may be sued in the place of performance of a contractual obligation, ${ }^{7}$ or the place where the harmful event occurred (for an action in tort). ${ }^{8}$ The general rule is further subject to the specific rules of exclusive jurisdiction. Irrespective of domicile, actions in rem that have as their object immovable property must be brought in the forum rei sitae, ${ }^{9}$ and actions relating to registered intellectual property (for example, patents and trademarks) must be brought in the courts of the country of registration. ${ }^{10}$ Where one of the parties is domiciled in a Contracting State and the parties have themselves agreed that a court of a Contracting State are to have jurisdiction in respect of particular matters, then that court shall have exclusive jurisdiction. ${ }^{11}$ European Court of Justice (ECJ) case law has held that these rules that derogate from the general rule of jurisdiction based on domicile are to be construed strictly and cannot give rise to an interpretation going beyond the cases expressly envisaged by the Brussels Convention. ${ }^{12}$

The ECJ has remarked that rules of special jurisdiction constitute an additional option for the plaintiff alongside the courts of the Contracting State in which the defendant is

4 Peter Jenard "Report on the Convention on Jurisdiction and the Enforcement of Judgments in Civil and Commercial Matters" (1979) OJ C 59/1, 15.

5 The 1968 Convention on Jurisdiction and the Enforcement of Judgments in Civil and Commercial Matters, art 2 [Brussels Convention].

6 Group Josi Reinsurance Company SA v Universal General Insurance Company [2000] ILPR 549; [2001] QB 68, para 35 (ECJ).

7 Brussels Convention, art 5 (1).

8 Brussels Convention, art 5 (3).

9 Brussels Convention, art $16(1)$

10 Brussels Convention, art 16 (4)

11 Brussels Convention, art 17.

12 Reunion Europeenne SA v Spliethoff's Bevrachtingskantoor BV [1998] ECR I-6511 (ECJ); Group Josi Reinsurance Company SA v Universal General Insurance Company [2000] ILPR 549; [2001] QB 68, para 49 (ECJ). 
domiciled, that being the general rule underlying the Brussels Convention. ${ }^{13}$ Thus, the ECJ is in effect acquiescing limited forum shopping in situations where the requirements of the general rule of jurisdiction and those of the special rules of jurisdiction are satisfied.

Furthermore, the Brussels Convention does not define domicile. This determination is left to the national law of the Contracting States. ${ }^{14}$ The importance of this point will become apparent later, but it suffices to say that this immediately creates an element of confusion.

Complementing these basic rules of jurisdiction, the Brussels Convention also provides rules pertaining to the situation where two courts are in conflict over jurisdiction. When the proceedings before two or more courts involve the same cause of action and the same parties, article 21 of the Brussels Convention requires any court other than the court first seised to, firstly, stay proceedings until the jurisdiction of the court first seised is established, and secondly, if so established, to decline jurisdiction. There is no element of discretion involved or consideration of factors relevant to an inquiry pursuant to a forum non conveniens claim. The sole consideration is whether the requisite elements of the mandatory rules of the Brussels Convention, or their limited exceptions, have been satisfied.

Supplementary to article 21, article 22 provides that where there are related actions pending in two or more Contracting States, any court other than the court first seised may, while the actions are pending at first instance, stay its proceedings if the law of that court permits consolidation of related actions and the court first seised has jurisdiction over both actions. Once again, the court first seised has priority, but the second court has a limited amount of discretion in determining whether the actions are related. Article 22 states that actions are deemed to be related where they are so closely linked that it is expedient to hear and determine them together to avoid the risk of irreconcilable judgments resulting from separate proceedings. The discretion, then, relates to the decision by the court seised second or later as to whether to await the outcome of the proceedings in the first court, so as to ensure consistency of judgments or to go ahead and risk irreconcilable judgments. ${ }^{15}$ Thus, article 21 is a mandatory provision, applicable where two actions are the same, and article 22, applicable only where proceedings are related and do not involve the same cause of action and the same parties, is more discretionary in nature.

In this way, the Brussels Convention provides limited rules for determining jurisdiction where two courts are seised. Articles 21 and 22 provide a simple court first seised rule, predicated of course upon the competing courts being competent pursuant to the rules of

13 Group Josi, above, para 40.

14 Brussels Convention, arts 52 and 53.

15 Wendy Kennett "Forum Non Conveniens in Europe" (1995) 54 CLJ 552, 553. 
jurisdiction provided for in the Convention. Questions of comparative appropriateness, unlike a forum non conveniens inquiry, are not relevant. The rules of the Brussels Convention itself stipulate what is appropriate. Indeed, the ECJ has emphasised that the Brussels Convention was designed in part to confer jurisdiction on the national court which was best qualified to determine a dispute, ${ }^{16}$ although there is also a recognition that the application of the rules may lead to a case being heard in a forum which does not have the closest connection with the dispute. ${ }^{17}$

It is in this regard that the question arises of the need for a discretionary power to stay an action in favour of another court that is argued to be more appropriate. It has been observed that in Continental Europe there exists a strong philosophical disapproval of judicial discretion in relation to jurisdiction. In Germany, for example, individuals have a constitutional right to have access to the courts to seek protection of their rights and the suggestion that a judge may exercise a discretion in deciding whether or not to retain jurisdiction is abhorrent. ${ }^{18}$ Furthermore, a strong argument could be made that, once jurisdiction has been established on the basis of accepted criteria, a plaintiff has a right to equal access to justice regardless of their domicile and regardless of the potential availability of an alternative forum. Such a strong advocacy of certainty in the allocation of jurisdiction has also been stressed by the ECJ in interpreting the Brussels Convention. ${ }^{19}$

\section{THE UNITED KINGDOM APPROACH TO JURISDICTION}

Standing in stark contrast to the Brussels Convention regime, the United Kingdom Courts have traditionally enjoyed wide jurisdictional powers based on service of process. Thus, where a defendant is validly served within the United Kingdom with notice of proceedings, the United Kingdom Courts have in personam jurisdiction as of right. ${ }^{20}$ Alternatively, the court may grant leave to serve proceedings on a defendant outside of the jurisdiction of the court provided the court is satisfied that the case is a proper one for service outside its jurisdiction. ${ }^{21}$ This "exorbitant" ${ }^{12}$ jurisdiction is counterbalanced by the

16 Effer SpA v Kantner [1982] ECR 825, 834 (ECJ).

17 Custom Made Commercial Ltd v Stawa Metallbau GmbH [1994] ECR I-2913, para 16-18 (ECJ).

18 Kennett, above, 560.

19 Custom Made Commercial Ltd v Stawa Metallbau GmbH, above, para 18.

20 See Dicey and Morris The Conflict of Laws (13th ed, Sweet \& Maxwell, London, 2000) Rule 22(1), 263.

21 RSC Ord 11, r 1(1).

22 As described by Peter F Schlosser "Report on the Convention on the Accession of the Kingdom of Denmark, Ireland, and the United Kingdom to the Brussels Convention" (1979) OJ C 59/71, paras 82 and 86 . 
doctrine of forum non conveniens, a common law power of the courts to grant a stay of proceedings where in the court's view there is an alternative forum in another jurisdiction which is competent to hear the case and which is the appropriate forum for the trial of the action, that is, in which the case may be tried more suitably for the interests of all parties and the ends of justice. Once the court is satisfied of the existence of an alternative competent forum, a stay will be granted unless the claimant can show that, even though there are factors connecting the proceedings with the foreign forum, substantial justice will not be obtained in the foreign jurisdiction. ${ }^{23}$ This regime provides a mechanism for determining which court has jurisdiction to hear proceedings that have a cross-border element to them and in respect of which more than one court is competent to hear the case.

Procedural rules changed, however, following the enactment of the Civil Jurisdiction and Judgments Act 1982, the legislation that gave effect in the United Kingdom to the Brussels Convention. As the learned authors of Dicey and Morris observe, where a claim relates to a civil or commercial matter within the scope of the Brussels Convention, the United Kingdom Court has jurisdiction to entertain a claim in personam solely in accordance with the provisions of the Convention. ${ }^{24}$ Where the Brussels Convention does not apply, in personam jurisdiction is based on the traditional common law rule of service of process.

The consistency of the idiosyncratic United Kingdom doctrine of forum non conveniens ${ }^{25}$ with the Brussels Convention has been the subject of much debate over the last decade. At the time of the United Kingdom's accession to the Brussels Convention, there was clear evidence of the reluctance of the United Kingdom to depart from the discretionary power of forum non conveniens in favour of the mandatory rules provided for in the Brussels Convention. When the United Kingdom acceded to the Brussels Convention in 1979, they tried to negotiate the introduction of a forum non conveniens clause in the Convention, allowing the United Kingdom Courts to retain the power to grant a stay on these grounds. This was resisted by the other member states, who argued that the provisions of the Brussels Convention itself have selected the convenient fora, all of them having some links to the case. ${ }^{26}$ The United Kingdom ultimately acquiesced. However, the power to grant a stay on these grounds is specifically preserved under section 49 of the Civil Jurisdiction and

23 Spiliada Maritime Corporation v Cansulex Ltd [1987] AC 460, 476-482 (HL) Lord Goff.

24 Dicey and Morris, above, Rule 22(2), 263.

25 Within the European Union, only the courts in the United Kingdom and Ireland recognise this discretionary power. See Mathias Reimann Conflict of Laws in Western Europe (Transnational Publishers, New York, 1995) 82.

26 Peter F Scholsser "Report on the Convention on the Accession of the Kingdom of Denmark, Ireland, and the United Kingdom to the Brussels Convention" (1979) OJ C 59/71, para 78. 
Judgments Act 1982 incorporating the Brussels Convention into United Kingdom law, in so far as it is not inconsistent with the principles of the Brussels Convention. ${ }^{27}$

The doctrine of forum non conveniens also enjoys strong judicial support. It would not be an overstatement to say that the United Kingdom Courts are quite attached to the doctrine. Lord Goff, writing for the House of Lords only a few years ago in Airbus Industrie GIE $v$ Patel could hardly contain his delight when he observed, in a postscript to his judgment, that several overseas jurisdictions had already adopted the doctrine, and further expressed his hope that it would continue to spread. Indeed, his Lordship described the principle as one of the most civilised of legal principles. ${ }^{28}$

Initial judicial examination, however, of the relationship between forum non conveniens and the Brussels Convention found in favour of a departure from this discretionary power in favour of the mandatory rules of the Convention. The High Court ruled in two cases that whenever an English domiciliary was sued in England in a civil or commercial matter, the effect of the Convention meant that the courts no longer had the power to stay proceedings for reasons of forum non conveniens, even if there were proceedings already pending before the courts of a non-contracting state. ${ }^{29}$ In both instances, English domiciled insurance companies were sued by United States plaintiffs and both sought to stay the English proceedings on forum non conveniens grounds. The High Court in these cases took the view that the exercise of discretion under the Brussels Convention was mandatory once invoked by plaintiff and that forum non conveniens, being a uniquely British discretionary power to decline jurisdiction, was incompatible with the scheme of the Brussels Convention. Regarding the scope of the Brussels Convention, Justice Hobhouse in Berisford held that: ${ }^{30}$

[i]t is clear that the Convention is designed to achieve uniformity and to 'harmonise' the relevant procedural and jurisdictional rules of the Courts of the Contracting States. The Convention leaves no room for the application of any discretionary jurisdiction by the court of [the United Kingdom]; the availability of such a discretion would destroy the framework of the Convention.

These two decisions were subsequently overruled by the Court of Appeal in In re Harrods (Buenos Aires) Ltd. This case involved a defendant company domiciled in the United Kingdom by virtue of its incorporation there. It was also domiciled in Argentina, which was

27 Civil Jurisdiction and Judgments Act 1982 (UK), s 49.

28 Airbus Industrie GIE v Patel [1999] 1 AC 119, 141 (HL) Lord Goff.

$29 S \mathcal{E} W$ Berisford Plc $v$ New Hampshire Insurance Co [1990] 2 QB 631 and Arkwright Mutual Insurance Co v Bryanston Insurance Co [1990] 2 QB 649.

30 Berisford, above, 645, Hobhouse J. 
the exclusive location of the company's business and its central management and control. The plaintiff was a Swiss domiciled company. The plaintiff brought proceedings in the United Kingdom and invoked article 2 of the Brussels Convention, arguing that the United Kingdom Courts, being the forum of the defendant's domicile, had mandatory jurisdiction that precluded a grant of a stay in favour of the courts in Argentina on the grounds of forum non conveniens.

In overruling the two previous first instance decisions, the Court of Appeal agreed in principle that a stay on the grounds of forum non conveniens was not available in cases where the two competing jurisdictions were both Contracting States (that is, England and another Contracting State). ${ }^{31}$ However it found that there was nothing to prevent the application of the doctrine when the conflict is between the courts of England and the courts of a nonContracting State. In the Court's view, the Convention did not apply. The scope of the Brussels Convention, then, was the determinative issue. In the view of the Court of Appeal, the scope of the Brussels Convention was effectively limited to conflicts of jurisdiction between courts of Contracting States only.

In arriving at this decision, the Court considered the true construction of the Brussels Convention. ${ }^{32}$ Lord Justice Dillon saw the Brussels Convention as implementing the aim of article 220 of the European Community Treaty which was essentially to simplify formalities between European Community-member states. A common basis of international jurisdiction in matters which fall within the scope of the Brussels Convention was seen as important in achieving this goal. ${ }^{33}$ Given that the Brussels Convention was merely an agreement between the Contracting States among themselves, Lord Justice Dillon did not feel that the framework of the Convention would be destroyed if there were available to the English Court a discretion to refuse jurisdiction, on the ground that the courts of a non-Contracting State were the appropriate forum, in a case with which no other Contracting State was concerned. ${ }^{34}$

Lord Justice Dillon did not regard as helpful the reports by Jenard and Schlosser that had concluded that forum non conveniens was incompatible with the Brussels Convention, because in the view of Lord Justice Dillon, Jenard and Schlosser had not contemplated that

31 In re Harrods (Buenos Aires) Ltd [1992] Ch 72, 93 (CA) Dillon LJ.

32 Harrods, above, 95.

33 Harrods, above, 96.

34 Harrods, above, 97. 
particular question. There were general statements in the reports which could be used as pointers either way, but nothing conclusive. ${ }^{35}$

At the present time, the United Kingdom Courts undoubtedly still regard Harrods as being the leading, and binding, judicial statement on the relationship between the Brussels Convention and the doctrine of forum non conveniens. In the recent case of Ace Insurance, ${ }^{36}$ the Court of Appeal applied Harrods and upheld a lower court ruling, decided around the same time as the Group Josi case discussed below, that there was still a discretion to grant a stay of proceedings on the grounds of forum non conveniens where the English court had jurisdiction by virtue of the Lugano Convention, a convention complementary to the Brussels Convention. ${ }^{37}$

Despite being recognised as the current leading United Kingdom case on the relation between the Brussels Convention and the doctrine of forum non conveniens, the Harrods decision is not free from controversy. The Court of Appeal ruling in Harrods was appealed, and the House of Lords, after hearing arguments from the parties for several days, referred the matter to the ECJ. However the case was ultimately settled without the ECJ issuing a ruling. ${ }^{38}$ Similarly, in the more recent case of Lubbe $v$ Cape Plc, ${ }^{39}$ the House of Lords again recognised the controversy and commented that were the case to turn on this issue, a ruling from the ECJ on the applicability of article 2 of the Brussels Convention would have been necessary. Indeed Lord Bingham hinted there that the correctness of Harrods is an issue and that whether article 2 of the Brussels Convention applies is not clear. ${ }^{40}$

Commentators have long pointed out that the lack of explicit reference within the Brussels Convention about the precise limits of its international operation has always been problematic and has contributed in large part to the uncertainty in the law regarding the

35 Harrods, above, 96.

36 Ace Insurance SA-NV v Zurich Insurance Company and Zurich America Insurance Company [2001] EWCA CIV 173 (CA).

37 The Lugano Convention is an agreement between the European Union members and the members of EFTA (European Free Trade Area). It is almost identical to the Brussels Convention and functionally it extends the jurisdictional rules of the Brussels Convention beyond the European Union to the EFTA states.

38 Ace Insurance, above, para 28.

39 Lubbe v Cape Plc [2000] 4 All ER 268 (HL) Lord Bingham. This is perhaps ironic given that Bingham LJ, as he then was, concurred with Dillon LJ in In re Harrods (Buenos Aires) Ltd [1992] Ch 72 (CA) in finding a limited scope of application of the Brussels Convention. See, In re Harrods (Buenos Aires) Ltd [1992] Ch 72, 98 (CA) Bingham LJ.

40 Lubbe v Cape Plc, above, 282. 
Convention. ${ }^{41}$ The preamble of the Brussels Convention refers to the determination of international jurisdiction of the Contracting Parties as necessary for the purpose of strengthening the legal protection of persons therein. ${ }^{42}$ The application of the Brussels Convention is thus predicated upon the existence of an international element, yet the Convention itself is silent as to the nature and extent of this requisite international element. A recent case decided by the ECJ, however, may have gone some way towards clarifying the extent of the scope of application of the Brussels Convention.

\section{THE GROUP JOSI CASE ${ }^{43}$}

The facts that gave rise to this case are as follows. The respondent, a Canadian insurance company, entered into a reinsurance contract with the appellant, a company domiciled in Belgium. The contract had been brokered by a French company, acting as agent of the respondent. Group Josi had been informed by the French agent that the main shareholders in the reinsurance contract were two United States reinsurance companies. Immediately prior to the acceptance of the reinsurance offer by Group Josi, the two United States companies informed the French agent that they intended to pull out of the reinsurance contract. This information was not passed on to Group Josi.

When the French agent sent Group Josi a statement of account a year later showing the amount owing in respect of Group Josi's share of the risk, Group Josi, which by this time had learned of the decision of the two United States companies to exit the deal, refused to pay, claiming that it had been induced to enter into the reinsurance contract on the basis of information which subsequently proved to be false.

UGIC brought proceedings against Group Josi in France. Group Josi argued that the French Courts lacked jurisdiction because the courts in Belgium had jurisdiction, pursuant to the Brussels Convention, based on the fact that the defendant's registered office was in Belgium. The French Court rejected this submission, holding that the Brussels Convention did not apply in respect of a Canadian company, and that the French Courts had jurisdiction by virtue of French domestic law. ${ }^{4}$

Group Josi appealed this ruling to the Versailles Court of Appeal. The Court observed that the question of whether the specific rules of the Brussels Convention can be used

41 See, for example, Adrian Briggs "Forum Non Conveniens and the Brussels Convention Again" (1991) 107 LMCLQ 180, 182.

42 Brussels Convention, preamble.

43 Group Josi Reinsurance Company SA v Universal General Insurance Company [2000] ILPR 549; [2001] QB 68 (ECJ).

44 Group Josi, above, para 26. 
against a plaintiff domiciled in a non-Contracting State involves the question of extending European Community law to non-member countries. Recognising that a decision on this question required an interpretation of the Brussels Convention, the Court referred the matter to the ECJ for a preliminary ruling.

The ECJ was asked: "Does the Brussels Convention apply not only to intra-Community disputes but also to disputes which are integrated into the Community? More particularly, can a defendant established in a Contracting State rely on the specific rules on jurisdiction set out in that Convention against a plaintiff domiciled in Canada?"45

In its judgment, the Court began by outlining the general scheme of the Brussels Convention as it relates to determination of jurisdiction. It noted that article 2 sets out the general rule that persons domiciled in a Contracting State are to be sued in the courts of that State, irrespective of the nationality of the parties. ${ }^{46}$

This fundamental principle may be derogated from in certain instances. The Court noted two categories of cases. First, where the fact situation is covered by a rule of special jurisdiction, the defendant may be excluded from the jurisdiction of the courts of the State in which it is domiciled and sued in a court of another Contracting State. Second, where a situation is covered by a rule of exclusive jurisdiction in relation to certain subject-matter, or a prorogation of jurisdiction, for example on the basis of a choice of forum clause, the defendant must be excluded from the jurisdiction of the courts of the State in which it is domiciled and sued in a court of another Contracting State. None of these specific rules were held to be relevant in this case.

The Court found, then, that it is only in quite exceptional cases that the domicile of the plaintiff is decisive in conferring jurisdiction. ${ }^{47}$ They concluded on the basis of their analysis of the scheme of the Brussels Convention that as a general rule the domicile of the plaintiff is not relevant for the purpose of determining jurisdiction pursuant to the Brussels Convention. Application of the rules of jurisdiction provided for in the Brussels Convention is dependent solely on the criterion of the defendant being domiciled in a Contracting State. ${ }^{48}$ This led to the conclusion that the rules of jurisdiction in the Brussels Convention may be applied to a dispute between a defendant domiciled in a Contracting State and a plaintiff domiciled in a non-member country. ${ }^{49}$

\footnotetext{
45 Group Josi, above, para 32.

46 Group Josi, above, para 34.

47 Group Josi, above, para 47.

48 Group Josi, above, para 57.

49 Group Josi, above, para 59.
} 


\section{WHERE TO FROM HERE? THE IMPACT OF GROUP JOSI}

Given the controversy surrounding the compatibility of the doctrine of forum non conveniens and the Brussels Convention, does the ECJ ruling in Group Josi change anything? While the ECJ was clear that the principles laid down by the Brussels Convention can be invoked by domicilaries of non-Contracting States, what is less clear are the implications of such a finding. Some commentators immediately sounded the death-knell for the doctrine of forum non conveniens, suggesting that a stay on the grounds of forum non conveniens is no longer available whenever the defendant is domiciled in the United Kingdom. ${ }^{50}$ It is questionable, however, whether Group Josi has this effect.

In Group Josi, the ECJ stated clearly that the domicile of the plaintiff is not relevant for the purpose of applying the rules of jurisdiction provided for in the Brussels Convention, and that the Brussels Convention can apply to a dispute between a defendant domiciled in a Contracting State and a plaintiff domiciled in a non-Contracting State. However, the ECJ did not expressly address the wider question of which cases the Brussels Convention can apply to.

It is important to recognise a difference between who can invoke the principles of the Brussels Convention and when the principles of the Brussels Convention apply. Consider a situation where a party to a dispute argues that a forum other than that of their domicile should hear the case. It is to the appropriateness of the desired forum in light of the jurisdictional rules that the Brussels Convention speaks, rather than to whether the party can invoke the rules given that they are domiciled in a particular jurisdiction. The Brussels Convention decides conflicts of jurisdiction where the case is connected with the European Union, not conflicts of domicile. This is so regardless of the domicile of the parties.

Indeed, the United Kingdom Courts have observed that the Harrods decision was based on the location of the competing fora and not on the respective domiciles of the parties. ${ }^{51} \mathrm{In}$ the Group Josi case, despite the fact that the plaintiff was domiciled in a non-Contracting State, the conflict of jurisdiction was between the courts of two Contracting States: The plaintiff contended that the courts of France had jurisdiction, while the defendant contended that the courts of Belgium had jurisdiction. Thus, the conflict was between courts of two Contracting States, and it is no surprise that the ECJ found the Brussels Convention applied to determine jurisdiction. On this interpretation, the decision in Group Josi does not break any significant new ground; the ratio merely confirms that it is possible for a domiciliary of a non-Contracting State to invoke the Brussels Convention when there is a

50 Douglas Peden "Litigator's View" (2000) The Lawyer, 13; John Melville Williams "Forum Non Conveniens, Lubbe v Cape and Group Josi v Universal General Insurance" (2001) 1 JPIL 72, 77.

51 Societe Commerciale de Reassurance v Eras International Ltd (No 2) [1995] 2 All ER 278, 298 (QB) Potter J. 
conflict of jurisdiction between Contracting States. The scope of application does not change from the Court of Appeal's interpretation in Harrods: The Brussels Convention applies to conflicts of jurisdiction between the courts of two Contracting States and in such instances the discretionary power to grant a stay on forum non conveniens grounds would not be available.

Do the mandatory rules of the Brussels Convention apply to a scenario where a domiciliary of a non-Contracting State sues a domiciliary of a Contracting State, and the conflict of jurisdiction is between courts of those two states or even a third country, also not a Contracting State, thereby precluding the availability of a plea of forum non conveniens? For example, consider a situation where a person domiciled in New Zealand sues a person domiciled in the United Kingdom, and the United Kingdom defendant argues that the case should be heard in New Zealand or even a third country that is also not a member of the European Union. The conflict of jurisdiction is between the United Kingdom and New Zealand or the United Kingdom and the third country. Does the Brussels Convention apply? Is the case to be heard in the defendant's domicile pursuant to the mandatory rule in article 2 of the Brussels Convention, and is the defendant precluded from seeking a stay of proceedings on the grounds of forum non conveniens in favour of a New Zealand or thirdcountry Court?

Group Josi would say that the mere fact that the plaintiff is domiciled in New Zealand does not in itself prevent the plaintiff from invoking the Brussels Convention. ${ }^{52}$ The wider question, however, is whether this is a conflict of jurisdiction to which the Brussels Convention speaks. It is on this point that the ECJ is silent. If the ratio of the Group Josi case is read as a statement on when the Brussels Convention can apply, as distinct from who can invoke the Brussels Convention, then this would represent a different and expansive view of the scope of the Convention, and would overrule the view of the Court of Appeal in Harrods. As this is a case involving a conflict of jurisdiction between the courts of a Contracting State and those of a competing forum, the requisite international element exists and the mandatory rules of the Brussels Convention apply. A discretionary stay on the grounds of forum non conveniens would, then, not be available whenever the defendant was domiciled in the United Kingdom, as it is inconsistent with the Brussels Convention.

It is submitted that while this interpretation may be a welcome outcome in terms of contributing to procedural certainty, it may be questioned whether Group Josi on its face goes this far. Interpreting the ratio in light of the facts of the case, the United Kingdom Courts may be cautious in regarding the decision as being a complete and authoritative statement on when the Brussels Convention applies. This is particularly so given the

52 Group Josi, above, para 57. 
apparent reluctance of the United Kingdom Courts to depart from the doctrine and the fact that the Harrods case itself was decided on the basis of competing fora, not the domiciles of the parties.

\section{RECONSIDERING THE SCOPE OF THE BRUSSELS CONVENTION IN LIGHT OF GROUP JOSI}

It may be possible, however, to reconstruct the argument in favour of finding an expansive scope to the Brussels Convention by drawing on elements of United Kingdom jurisprudence and observations of the ECJ. United Kingdom Courts have accepted that where jurisdiction is conferred upon a court pursuant to an international convention dealing with particular matters, the question of whether a stay of proceedings on the grounds of forum non conveniens is available depends on whether the doctrine is expressly or impliedly permitted by the particular convention. ${ }^{53}$ The case of Milor Srl v British Airways Plc involved the determination of jurisdiction pursuant to the Warsaw Convention 1929 dealing with aviation matters. The Court of Appeal noted the Warsaw Convention provisions dealing with jurisdiction were a jurisdictional code agreed upon by the Contracting Parties which provided the plaintiff with a limited choice of competent jurisdictions, each of which to a greater or lessor degree was likely to be appropriate for the bringing of a claim and it was implicit that there was no scope for an individual court to impose a venue that conflicted with the plaintiff's choice. ${ }^{54}$ In addition, only a small number of signatory countries recognised the doctrine of forum non conveniens and the Court observed that it would be surprising if the contracting parties to the convention had preserved to that small minority of countries which applied the doctrine of forum non conveniens a power to affect the choice of the forum in which a dispute should be tried by a process unknown to the majority of the parties. ${ }^{55}$ On this basis, then, the doctrine was found to be incompatible with the Warsaw Convention.

The essence of the reasoning, then, is the question of the survival of forum non conveniens vis-à-vis an international convention depends on whether it can be applied consistently with the convention in question. What about the Brussels Convention? As a starting point it should be noted that the 1982 implementing legislation provides that "any question as to the meaning or effect of the [Brussels] Convention shall, if not regarded to the European Court in accordance with the Protocol of 1971, be determined in accordance with the principles

53 Milor Srl v British Airways Plc [1996] QB 702 (CA).

54 Milor, above, 708.

55 Milor, above. 
laid down by and any relevant decision of the European Court. ${ }^{56}$ This was also the starting point for the Court in Harrods, who observed that the answer to the question before the court depends on the true construction of the Brussels Convention and that is a matter of European law. ${ }^{57}$

The Brussels Convention does not expressly permit the exercise of forum non conveniens, and following the same reasoning as the Court in Milor, as only a small minority of Brussels Convention Contracting States recognise the doctrine of forum non conveniens, it would be implicit that the doctrine is unavailable where jurisdiction is conferred pursuant to the Brussels Convention. Furthermore, regarding the interpretation of provisions of the Brussels Convention, the ECJ in Group Josi stressed that there can be no derogations from the general rule that the courts of the defendant's domicile have jurisdiction except for those expressly provided for in the Convention, and these exceptions must be construed strictly. ${ }^{58}$

Given also that the doctrine of forum non conveniens is a mechanism for curtailing the excesses of common law jurisdiction in disputes involving two common law jurisdictions, it seems odd that the doctrine could survive where jurisdiction could be appropriately determined on the basis of alternative principles clearly articulated in an international instrument. The rules in the Brussels Convention determine appropriateness, and an additional discretionary examination of the suitability of the forum is superfluous at best.

The conclusion, then, seems clear: Where the Brussels Convention applies, the doctrine of forum non conveniens cannot. The question of compatibility of the doctrine with the Brussels Convention does not in a strict sense arise: the two are, in their current form, incompatible. This is indeed the conclusion reached by Schlosser in his report on the Brussels Convention. ${ }^{59}$

Again, this is not inconsistent with Harrods. The Harrods decision implied that the doctrine would be precluded where the Brussels Convention was held to be applicable. The Court of Appeal agreed in principle that a stay on the grounds of forum non conveniens was not available in cases where the two competing jurisdictions were both Contracting States

56 Civil Jurisdiction and Judgment Act 1982 (UK), s 3(1). The ECJ can give definitive rulings on the interpretation of the Brussels Convention pursuant to article 1 of the 1971 Protocol on Interpretation.

57 In re Harrods (Buenos Aires) Ltd [1992] Ch 72, 95 (CA) Dillon LJ.

58 Group Josi Reinsurance Company SA v Universal General Insurance Company [2000] ILPR 549; [2001] QB 68 , para 49 (ECJ).

59 Peter F Scholsser "Report on the Convention on the Accession of the Kingdom of Denmark, Ireland, and the United Kingdom to the Brussels Convention" (1979) OJ C 59/71, para 78. 
(that is, England and another Contracting State) ${ }^{60}$ However, it found that there was nothing to prevent the application of the doctrine when the conflict is between the courts of England and the courts of a non-Contracting State. In the Court's view, the Brussels Convention did not apply.

This view of the Brussels Convention as only regulating jurisdiction as between Contracting States was echoed by Lord Goff in the Airbus Industrie case, where he remarked that "the primary purpose of the Convention is to ensure that there shall be no clash between the jurisdictions of member states of the Community". 61

Such a narrow view of the scope of the Convention has been criticised, however, by a number of commentators. The predominant view, particularly in Continental Europe is that the Brussels Convention has universalistic effect: It is intended to set mandatory rules of jurisdiction for the Contracting States for all disputes that fall within its subject matter and personal scope. ${ }^{62}$ The Jenard report described one of the purposes of the Brussels Convention as achieving the greatest possible legal certainty by establishing common rules of jurisdiction. ${ }^{63}$ Interpreting the Brussels Convention as having universalist effect, it is argued, ensures predictability and certainty and also that those domiciled in a Contracting State have equal rights and obligations. ${ }^{64}$ Indeed, this is the essence of Justice Hobhouse's reasoning in Berisford, the first instance decision that held that the Brussels Convention can apply to a conflict of jurisdiction between a court of a Contracting State and those of nonContracting States. ${ }^{65}$

The question arises, then, which disputes fall within the subject-matter and personal scope of the Brussels Convention? It has been observed that the text of the Brussels Convention itself contains no indications that any limitations on its application are intended. ${ }^{66}$ How, then, ought the Brussels Convention be construed?

Crucially, the judgment of the ECJ in Group Josi could be read as addressing a key concern of the United Kingdom Court of Appeal in Harrods. Dillon LJ remarked that if article 2 of the Brussels Convention has full mandatory effect in cases where the defendant

60 Harrods, above, 93.

61 Airbus Industrie GIE v Patel [1999] 1 AC 119, 132 (HL) Lord Goff.

62 See, for example, Wendy Kennett "Forum Non Conveniens in Europe" (1995) 54 CLJ 552, 562.

63 P Jenard "Report on the Convention on Jurisdiction and the Enforcement of Judgments in Civil and Commercial Matters" (1979) OJ C 59/1, 15.

64 Kennett, above.

65 S E W Berisford Plc v New Hampshire Insurance Co [1990] 2 QB 631. 645 Hobhouse J.

66 Kennett, above. 
is domiciled in England and the plaintiff is domiciled overseas, an agreement between the parties to submit to the jurisdiction of a foreign court would be useless, as English Courts would find themselves bound to hear the case pursuant to the mandatory provisions of article 2. However the ECJ stated that special rules of exclusive jurisdiction as provided in article 17 are equally applicable if the defendant is domiciled in a Contracting State and the plaintiff is domiciled in a non-member country. ${ }^{67}$ Thus a choice of forum clause would be upheld under the Brussels Convention, even where the defendant is domiciled in a Contracting State.

Another recent decision by the ECJ appears to further support this view. In Coreck Maritime $v$ Handelsveem, the ECJ stated that the first paragraph of Article 17 of the Brussels Convention, relating to choice of forum clauses, applies only if, first, at least one of the parties to the original contract is domiciled in a Contracting State and, secondly, the parties agree to submit any disputes before a court or the courts of a Contracting State. ${ }^{68}$ Thus it appears that the ECJ does indeed see the Brussels Convention as applicable even where only one of the parties is domiciled in a contracting state and the potential conflict of jurisdiction is between courts of a Contracting State and a non-Contracting State.

Interestingly too, there is evidence that United Kingdom Courts are prepared to accept an expansive application of the principles of the Brussels Convention and hold that exclusive jurisdiction clauses of the kind countenanced by article 17 should be applied even where the clause was in favour of a non-Contracting State. In Ace Insurance, the trial judge, Justice Longmore, remarked that it would be odd if an agreement to submit to the jurisdiction of the courts of a non-Contracting State had to be treated as ineffective in any Brussels Convention country. ${ }^{69}$

On the basis of this the reasoning of the Court of Appeal in Harrods begins to break down. If the court was faced with a situation where the parties were both domiciled in Contracting States and there was an agreement between the parties to submit to the jurisdiction of the courts of a non-Contracting State, would the court, given that the case involves a dispute between two domiciliaries of Contracting States, apply the mandatory provisions of the Brussels Convention and hold that the case must be heard in England? It is submitted that the United Kingdom Courts would uphold the choice of forum clause, even

67 Group Josi Reinsurance Company SA v Universal General Insurance Company [2000] ILPR 549; [2001] QB 68, paras 41-42 (ECJ).

68 Coreck Maritime GmdH v Handelsveem BV (2000) Case C-387/98 (OJ C 28, 27/01/2001).

69 Ace Insurance SA-NV v Zurich Insurance Co and Zurich America Insurance Co [2000] 2 Lloyd's Rep 423, para $21(\mathrm{QB})$ Longmore J. 
though there is a conflict of jurisdiction between courts of a Contracting State and those of a non-Contracting State. ${ }^{70}$ Logically, this suggests one of three conclusions:

- The mandatory provisions of the Brussels Convention are not so mandatory after all;

- The distinction between domiciliaries and courts of Contracting States and those of non-Contracting States is not a tidy one;

- The rules of the Brussels Convention can be held to apply in circumstances analogous to the provisions of the Brussels Convention. Thus, the choice of forum clause would be upheld, granting exclusive jurisdiction to the chosen forum pursuant to article 17 , applying mutatis mutandis. ${ }^{71}$

The first proposition would totally undermine the Brussels Convention. The aim of the Brussels Convention is to provide mandatory rules for the determination of jurisdiction in matters that come within the scope of the Convention, and to therefore achieve the greatest possible legal certainty. ${ }^{72}$ Any wavering from this position would inevitably create legal uncertainty. Arguably, the better view is a combination of the latter two propositions. In short, the Brussels Convention operates more effectively if it is read as being equally applicable in a situation where the defendant is domiciled in a Contracting State and the plaintiff in a non-Contracting State, and where there is a conflict of jurisdiction between the courts of Contracting State and non-Contracting State. The connection with Europe is satisfied and the provisions of the Brussels Convention can be applied to settle the conflict.

Continental European writers have long argued for recognition of a reflexive effect of the Brussels Convention. Thus, while it is conceded that the Brussels Convention cannot, and should not, confer jurisdiction on the courts of a non-Contracting State, the principles of the Brussels Convention can nevertheless be applicable where a non-Contracting State asserts jurisdiction on a basis that is accepted within the Brussels Convention as conferring exclusive jurisdiction on that court. The assertion by the court of the non-Contracting State will be taken into account and the principles inherent in the Brussels Convention will be applied accordingly. ${ }^{73}$

70 Indeed, this much can be said given the remarks by Longmore J in Ace Insurance, above.

71 The United Kingdom Courts have already made judicial reference to academic discussion of application of Convention principles by analogy. See Ace Insurance SA-NV $v$ Zurich Insurance Company and Zurich America Insurance Company [2001] EWCA CIV 173, para 40 (CA).

72 P Jenard "Report on the Convention on Jurisdiction and the Enforcement of Judgments in Civil and Commercial Matters"(1979) OJ C 59/1, 15.

73 Wendy Kennett "Forum Non Conveniens in Europe" (1995) 54 Camb LJ 552, 563. 
The principles could be used, for example, to enforce a choice of forum clause conferring exclusive jurisdiction on a court, either by conferring jurisdiction on a Contracting State or by operating to force a stay of proceedings commenced in a Contracting State in a case where the choice of forum clause provided that a court in a non-Contracting State has competent jurisdiction. Such an interpretation is suggested as providing a compromise between the extreme positions of a complete denial and a total acceptance of forum non conveniens. ${ }^{74}$

Is this extra-territorial application of a convention to countries not a party to the convention? Strictly speaking, no it is not. It is not conferring jurisdiction on the courts of a non-Contracting State and it is not precluding a case from being heard in the courts of a non-Contracting State. Where the private international law rules of a non-Contracting State operate so as to grant jurisdiction over a case to a court in a manner consistent with the Brussels Convention, the rules of the Brussels Convention can be applied if proceedings are brought in the courts of a Contracting State so as to address the conflict of jurisdictions between those two courts. The lis pendens, or related actions rules, could be applied by a court in a Contracting State to stay proceedings in a court in a Contracting State where proceedings have already been brought in the courts of a foreign jurisdiction on the basis of criteria recognised by the Brussels Convention. In this way, the provisions of the Brussels Convention could operate to decide conflicts of jurisdiction, without the need for discretionary intervention by the courts.

While the Brussels Convention contributes greatly to simplicity and predictability in cross-border litigation by determining the appropriate jurisdiction on the basis of clearly articulated rules, the Brussels Convention scheme is not without its problems. The ECJ in Group Josi observed ${ }^{75}$ that a plaintiff may avail themselves of a choice between jurisdiction on the basis of the defendant's domicile ${ }^{76}$ and jurisdiction on the basis of fact-specific criteria such as place of performance of contract. ${ }^{77}$ This creates an opportunity for forum shopping.

The prevention of forum shopping is often cited as one of the justifications for the use of the discretionary power of forum non conveniens. ${ }^{78}$ The United Kingdom Courts have,

74 Kennett, above, 564.

75 Group Josi Reinsurance Company SA v Universal General Insurance Company [2000] ILPR 549; [2001] QB 68 , para 40 (ECJ).

76 Brussels Convention, art 2.

77 Brussels Convention, art 5.

78 Daniel Dorward "The Forum Non Conveniens Doctrine and the Judicial Protection of Multinational Corporations from Forum Shopping Plaintiffs" (1998) 19 U Penn J Intl Eco L 141, 158. 
however, exhibited some degree of ambivalence in regards to the possibility of limited forum shopping under international conventions dealing with jurisdiction matters. In Milor Srl $v$ British Airways Plc, the Court noted that the Warsaw Convention provided the plaintiff with an option of bringing proceedings in a multiplicity of fora. ${ }^{79}$ The Court was not prepared to nullify this option, and rejected an argument that a stay was nevertheless available on the ground of forum non conveniens. Indeed, the Court went out of its way to preserve the option for the plaintiff.

In summary, then, a reexamination of the Brussels Convention in light of European and United Kingdom jurisprudence suggests that the Convention operates logically and effectively if it is interpreted as being applicable to all international disputes that have an appropriate European element, for example a defendant domiciled in a Contracting State, facts that give rise to special jurisdiction in terms of article 5, or a choice of forum clause in terms of article 17. This is the case even if the conflict of jurisdiction is between courts of a Contracting State and a non-Contracting State. The nature of the case is international, and the Brussels Convention applies to determine the appropriate forum on the basis of clearly articulated rules.

\section{AMENDING THE CONNECTING FACTOR REQUIREMENTS FOR DOMICILE}

As argued above, there is strong support within the ECJ for the view that the Brussels Convention is applicable where only one party to a dispute is domiciled in a Contracting State. This is supported by academics, particularly in mainland Europe. ${ }^{80}$ Furthermore, there is evidence of a growing acquiescence of this interpretation within United Kingdom Courts. If this is accepted as the true scope of application of the Brussels Convention, then a stay of proceedings on the grounds of forum non conveniens would be unavailable where the defendant was domiciled in the United Kingdom or alternatively where any of the rules of special jurisdiction or exclusive jurisdiction were satisfied, resulting in the United Kingdom Courts having jurisdiction under the Brussels Convention.

Acceptance of an expansive scope of application of the Brussels Convention may, however, create situations that the doctrine of forum non conveniens was designed to avoid in particular, a case being heard in a jurisdiction with very little substantial link with the dispute. In Harrods, for example, the Court of Appeal was certainly mindful of the fact that Argentina was a more appropriate forum than England. The defendant company was incorporated in England, and by virtue of this formal connection was deemed to be

79 Milor Srl v British Airways Plc [1996] QB 702 (CA).

80 Wendy Kennett "Forum Non Conveniens in Europe" (1995) 54 Camb LJ 552, 563. 
domiciled in England for the purposes of the Civil Jurisdiction and Judgments Act 1982. ${ }^{81}$ This was despite the fact that in substance all the business of the company was done in Argentina, which was also the place of effective management of the company. Now, if the mandatory rules of the Brussels Convention were to apply, England would have jurisdiction by virtue of the defendant's domicile and a stay of proceedings on the grounds of forum non conveniens in favour of proceedings in Argentina would be unavailable. The application of the Brussels Convention was, of course, rejected by the Court.

However, this situation could be remedied by a revision of the definition of domicile of a corporation for purposes of jurisdictional matters. Article 53 of the Brussels Convention allows Contracting States to determine for themselves the connecting factors necessary to establish domicile. Section 41 of the Civil Jurisdiction and Judgments Act 1982 provides that an individual is domiciled in the United Kingdom if he or she is resident there. Section 42 adopts a dual definition for the determination of the domicile of a corporation: A corporation is domiciled in England if it is incorporated under United Kingdom law or its central management and control is located in the United Kingdom. ${ }^{82}$

The use by the United Kingdom of the place of incorporation as an appropriate connecting factor for the determination of a corporation's domicile is somewhat rare among European States, with only the Netherlands employing a similar criterion. ${ }^{83}$ A more common criterion is the place of effective management or control or the principle place of business. ${ }^{84}$ This is seen as a more appropriate connecting factor and basis for determining domicile.

Adoption by the United Kingdom of an alternative standard for determining domicile, more in line with other European countries, could go some way towards addressing a practical concern with applying the mandatory provisions of the Brussels Convention on a wider basis. It would reduce the risk of a case being heard in a forum inappropriate in terms of its degree of connection to the parties and the case as a whole, and thus obviate the need for a discretionary power such as forum non conveniens.

81 Civil Jurisdiction and Judgments Act 1982, s 42(3)(a).

82 Civil Jurisdiction and Judgments Act 1982, s 42(3).

83 See, for example, article 10(2) of the Dutch Civil Code. See also, Stephen O'Malley and Alexander Layton European Civil Practice (Sweet \& Maxwell, London, 1989) para 55.26.

84 See, for example, O'Malley and Layton, above, chs 48-58. In particular, see para 26 of each chapter. 


\section{ADOPTION OF A MORE LIMITED FORM OF FORUM NON CONVENIENS?}

Given the almost infinite possible fact situations that can arise in cross-border disputes, it might be argued that some degree of flexibility ought to be available to ensure that the case is heard in the most suitable forum, rather than jurisdiction being decided by a purely mechanical application of specific criteria. Thus, in reexamining the doctrine of forum non conveniens and its relationship with the Brussels Convention, alternative approaches might also be considered.

Firstly, it is noteworthy that the United Kingdom doctrine of forum non conveniens has not been adopted by all common law countries. Australian Courts, for example, have rejected the Spiliada approach. The Spiliada test is essentially a two step analysis, involving first a requirement that the defendant show that there is available a more appropriate forum, that is, one in which the case could be tried more suitably for the interests of all parties and for the ends of justice, and secondly, once the defendant has established a prima facie case for a stay, the plaintiff has the burden of showing that there are circumstances by reason of which justice requires that the United Kingdom Court exercise its jurisdiction. ${ }^{85}$ The Australian Courts, on the other hand, adopt a narrower test. Instead of looking to whether there is a clearly more appropriate forum abroad, the Australian doctrine examines whether the Australian forum is "clearly inappropriate", that is, seriously and unfairly burdensome, prejudicial, or damaging to the defendant. ${ }^{86}$ Justice Deane, in supporting this approach, stated that "it is a basic tenet of our jurisprudence that, where jurisdiction exists, access to the courts is a right. It is not a privilege which can be withdrawn otherwise than in clearly defined circumstances". 87

A further alternative approach is offered by the Special Commission of the Hague Conference on Private International Law charged with the task of authoring a draft international convention on jurisdiction and enforcement of foreign judgments in civil and commercial matters. One of the more contentious matters during the drafting process was the question of the adoption of a forum non conveniens clause and a lis pendens clause. ${ }^{88}$

The draft convention provides for limited forum non conveniens test which represents a compromise between the competing philosophies of common law and civil law countries.

85 Spiliada Maritime Corporation v Cansulex Ltd [1987] AC 460, 476-482 (HL) Lord Goff.

86 Oceanic Sun Line Special Shipping Co Inc v Fay [1988] 165 CLR 197, 247 Deane J. The test was subsequently confirmed in Voth v Manildra Flower Mill Pty [1990] 171 CLR 538.

87 Ocean Sun Line Special Shipping Co Inc v Fay [1988] 165 CLR 197, 252 Deane J.

88 See Martine Stuckelberg "Lis Pendens and Forum Non Conveniens at the Hague Conference" (2001) 26 Brook J Intl L 949, 954. 
The draft convention allows the suspension of a case, in exceptional circumstances, if the court seised is clearly inappropriate to decide the case and if a court of another State has jurisdiction and is clearly more appropriate to resolve the dispute. ${ }^{89}$ The language is similar to that of the Australian approach, in that a greater emphasis is placed on the unsuitability of the forum seised and could be seen as moving away from the wider United Kingdom approach. The draft provides an illustrative list of factors to be taken into account by the court in coming to its decision, including the parties' habitual residence, the nature and location of the evidence and procedures for obtaining such evidence, time limitations, and the possibility of recognition and enforcement of a judgment on its merits. ${ }^{90}$ Under the draft regime, the court granting the stay specifies the time frame during which proceedings must be brought in the alternative forum. If this time frame is not adhered to or the alternative forum declines to exercise jurisdiction, then the original court shall exercise jurisdiction. ${ }^{91}$

While both the Australian approach and the draft convention appear to limit the instances in which a stay of proceedings for reasons of forum non conveniens would be granted, the proposed scheme does not in any real sense move away from the discretionary regime provided for in United Kingdom law. The mere fact that the court has the discretion to grant a stay in itself creates the uncertainty and the potential for additional costs in crossborder litigation. While the Australian and draft convention approaches may reduce the number of successful applications for a stay, they arguably will not stop defendants from trying. That is ultimately the weakness of the discretionary regime.

\section{CONCLUSIONS - THE FUTURE OF FORUM NON CONVENIENS IN THE UNITED KINGDOM}

It has been suggested that the retention of a discretion based on forum non conveniens is a way of avoiding the devotion of scarce judicial resources to cases that have only a minimal linkage with the United Kingdom, as indeed was the case in Harrods. ${ }^{92}$ Yet forum non conveniens litigation can often be just as time consuming and costly as a substantive hearing,

89 The Hague Conference Preliminary Draft Convention on Jurisdiction and Foreign Judgments in Civil and Commercial Matters (Preliminary Draft), article 22(1). The draft convention was adopted in October 1999 and is available in the Hague Conference website at <http://www.hcch.net/e/conventions/draft36e.html> (last accessed August 28, 2001).

90 Preliminary Draft, article 22(2).

91 Preliminary Draft, article 22(5).

92 Martine Stuckelberg "Lis Pendens and Forum Non Conveniens at the Hague Conference" (2001) 26 Brook J Intl L 949, 964. 
nullifying any gain in judicial economy. Such arguments have also not gone unnoticed by United Kingdom Courts. In Milor, Lord Justice Phillips observed that: ${ }^{93}$

[w]here, as so often, substantial costs are incurred in interlocutory battles in relation to jurisdiction, I have a suspicion that the object of the exercise is frequently not to ensure that the trial takes place in the appropriate forum, but to achieve a better negotiating stance in the action which neither side expects to get to trial. There is something to be said for a regime which restricts the choice of forum in a manner which excludes those which are likely to be inappropriate, but which does not otherwise permit the plaintiff's choice to be challenged.

The abuse of forum non conveniens in this manner was probably not contemplated by the House of Lords when they reformulated the doctrine some fifteen years ago. Lord Templeman, in his brief speech in the Spiliada case, expressed his hope that the newly formulated forum non conveniens test would be applied by a first instance judge in chambers after quiet contemplation of written submissions, the issue being resolved in a matter of hours and without the added complication of appeals. ${ }^{94}$ Unfortunately, the reality has proved to be somewhat different.

Indeed, the need for increased certainty of procedure in international dispute cases can be supported by reference to the protracted interlocutory litigation that occurred recently in the Lubbe $v$ Cape Plc case. ${ }^{95}$ This case involved a personal injury claim by South African workers who suffered disease (in some cases died) from working in an asbestos mine owned and operated by a company domiciled in the United Kingdom. The plaintiffs commenced proceedings for compensation in the United Kingdom, but were immediately met by a barrage of interlocutory motions, including an application for a stay of proceedings on the ground of forum non conveniens. The defendant argued that the case should be heard in South Africa. After no less than three first instance hearings, two appeals to the Court of Appeal, and finally, a House of Lords decision, the defendant's application for a stay was denied; the plaintiffs would get their day in a United Kingdom Court. But this merry-goround of interlocutory litigation could have been avoided if the Brussels Convention had, from the outset, been held to apply. On the basis that the defendant was domiciled in the United Kingdom, the United Kingdom Courts would have jurisdiction under article 2 of the Brussels Convention, and the possibility of a stay on the ground of forum non conveniens would be unavailable.

93 Milor Srl v British Airways Plc [1996] QB 702, 710 (CA) Phillips LJ.

94 Spiliada Maritime Corp v Cansulex Ltd [1987] 1 AC 460, 465 (HL) Lord Templeman.

95 Lubbe v Cape Plc [2000] 4 All ER 268 (HL). 
There is much to be said for certainty and the avoidance of protracted interlocutory litigation, particularly in cases of a transnational nature where the potential for burgeoning litigation costs is apparent. Extending the scope of application of the Brussels Convention would go a long way towards achieving this in situations where a defendant domiciled in the United Kingdom is being sued in United Kingdom Courts. Group Josi arguably settles the question of whether the fact that one of the parties is not a domiciliary of a Contracting State will prevent the Brussels Convention from being invoked. The Court found it will not. While the Group Josi case arguably does not settle the wider issue, in that it does not expressly address the question of the application of the Brussels Convention to a situation where there is a conflict of jurisdiction between the courts of a Contracting State and those of a non-Contracting State, it most certainly should be seen as an important step in the right direction. While there is evidence that the United Kingdom Courts are beginning to warm to such a development, the need for a conclusive decision on this matter is clear.

It is further submitted that the potential for cases to be heard in jurisdictions that have no more than a minimal link with the dispute, seen as a justification for the exercise of a discretionary stay, could be immediately alleviated by amending the provisions in the Civil Jurisdiction and Judgment Act 1982 that provide the criteria for determining the domicile of a company. To hold that for the purposes of jurisdiction a company is domiciled in the country of its incorporation, while formalistically satisfactory, can nevertheless give rise to the unsatisfactory conclusion that the company must be sued in a country in which, in a substantive sense, does not represent the country in which it carries on its business nor is its centre of management and control.

An amendment rejecting the place of incorporation as the domicile of a company would make the application of the Brussels Convention to a case where the plaintiff was a domiciliary of a non-Contracting State less problematic. This would ensure a strong European connection to the case, notwithstanding that there is a non-European element, thus obviating the need for a discretionary power.

The implication for companies and practitioners in New Zealand and other nonEuropean countries contemplating the future possibility of litigating in the United Kingdom is clear. The Brussels Convention may be poised to become the sole determinant of conflicts of jurisdiction, where the defendant is domiciled in the United Kingdom or other substantive provisions are satisfied, and there is a need to be watchful of future judicial developments on this issue. Such a development ought to be welcomed as a positive step towards adding clarity and certainty to international litigation. 
